NOTE

\title{
Low consumption of virus-sized particles by heterotrophic nanoflagellates in two lakes of the French Massif Central
}

\author{
Y. Bettarel ${ }^{1, *}$, T. Sime-Ngando ${ }^{2}$, M. Bouvy ${ }^{1}$, R. Arfi ${ }^{1}$, C Amblard ${ }^{2}$ \\ ${ }^{1}$ Centre IRD (Institut de Recherche pour le Développement) de Bel Air, UR 167 CYROCO, BP 1386, Dakar, Senegal \\ ${ }^{2}$ Laboratoire de Biologie des Protistes, UMR CNRS 0623, Université Blaise Pascal (Clermont-Ferrand II), \\ 63177 Aubière Cedex, France
}

\begin{abstract}
Seasonal and depth-related variability in the grazing activity of heterotrophic nanoflagellates (HNF) on viruses was examined in the oligo-mesotrophic Lake Pavin and in the eutrophic Lake Aydat, French Massif Central, between May and November 2000. Ingestion rates (IR) were determined using $50 \mathrm{~nm}$ diameter fluorescent microspheres, as virus analogues. In both lakes, highest grazing activities on virus-sized particles were recorded in the metalimnion, at the beginning and the end of the thermal stratification period. Estimated IRs in Lake Pavin (mean $=0.4$ viruses $\mathrm{HNF}^{-1}$ $\mathrm{h}^{-1}, \mathrm{CV}=38.0 \%$ ) and in Lake Aydat (mean $=0.3$ viruses $\mathrm{HNF}^{-1} \mathrm{~h}^{-1}, \mathrm{CV}=35.6 \%$ ) were not significantly different, in contrast to clearance rates (CR), which were significantly higher in the oligomesotrophic $\left(2.3 \times 10^{-2} \mathrm{nl} \mathrm{HNF}^{-1} \mathrm{~h}^{-1}\right)$ than in the eutrophic lake $\left(0.7 \times 10^{-2} \mathrm{nl} \mathrm{HNF}^{-1} \mathrm{~h}^{-1}\right)$. CRs for viruses were correlated with CRs for bacteria in Lake Aydat but not in Lake Pavin, suggesting a greater abundance within the HNF assemblages of virus-sized particle feeders in the less productive lake. We estimated that 4.1 and $0.8 \%$ of viral production were grazed by HNF in Lake Pavin and Lake Aydat, respectively. Finally, although viruses seem to represent a minor food source for HNF (i.e. compared to bacteria), they may not be inconsequential in their diet, especially in oligotrophic lakes.
\end{abstract}

KEY WORDS: Lakes · Viruses · Heterotrophic nanoflagellates · Microbial food web · Predation

\section{INTRODUCTION}

With abundances typically surpassing $10^{7}$ particles $\mathrm{ml}^{-1}$ in both fresh and marine waters, viruses are now recognized as a key component in structuring the aquatic microbial food web (Fuhrman 1999, Wommack \& Colwell 2000, Sime-Ngando et al. 2003, Weinbauer 2004). Although viruses potentially infect all aquatic organisms, prokaryotes and eukaryotic phytoplankton are doubtless their major hosts, whose entire production may be occasionally controlled by these pathogens (Noble \& Fuhrman 2000, Fischer \& Velimirov 2002).
Furthermore, evidence is accumulating that viruses are also involved in nutrient cycling (Middelboe \& Lyck 2002), influence bacterial and algal diversity (Šimek et al. 2001, Mann 2003, Weinbauer \& Rassoulzadegan 2004) and contribute to the demise of phytoplankton monospecific blooms (Bratbak et al. 1993, Suttle 2000, Brussaard 2004).

With sizes commonly comprising between 20 and $200 \mathrm{~nm}$ (i.e. the diameter of the capsid), aquatic viruses consequently contribute to the DOM pool and may potentially represent a food source for small grazers. On the basis of this consideration, Gonzàlez \& Suttle 
(1993) investigated grazing on viruses and virus-sized particles by natural assemblages and cultures of marine nanoflagellates using both fluorescent microspheres and labelled viruses. Despite the fact that bacteria are undoubtedly the principal constituent in the diet of heterotrophic nanoflagellates (HNF) in most aquatic systems (Sanders et al. 1992, Sherr \& Sherr 1994), Gonzàlez \& Suttle (1993) showed that viruses can also contribute significantly to the nutrition of HNF and that being consumed is one possible route for the decay of virioplankton in addition to degradation by solar radiation (Suttle \& Chen 1992, Wilhelm et al. 1998), by heat-labile substances (Noble \& Fuhrman 1997), or by adsorption to particulate organic matter (Kapuscinski \& Mitchell 1980).

However, this novel microbial trophic link (i.e. viruses > HNF) has not been explored further as Gonzàlez \& Suttle's (1993) work remains the only report on this topic so far. In the present study, we attempt to further examine this trophic link by investigating, for the first time in freshwater, HNF consumption of fluorescent latex virus-sized spheres. By investigating the seasonal variability in HNF 'virivory' in 2 lakes of distinct trophic status, we can confirm the ability of phagotrophic nanoflagellates to graze on virussized particles and discuss the significance and ecological implications of this activity.

\section{MATERIALS AND METHODS}

Samples were collected from 2 lakes of the French Massif Central differing in trophic status. Lake Pavin is a dimictic, meromictic oligo-mesotrophic lake located at $1197 \mathrm{~m}$ altitude and characterized by a maximum depth of $92 \mathrm{~m}$ and a small surface area (44 ha). Lake Aydat is also small (surface area: 60 ha; maximum depth: $15 \mathrm{~m}$ ) and is a eutrophic, dimictic lake located at $825 \mathrm{~m}$ altitude. Water samples were collected monthly from April to November 2000 using a 10 l Van Dorn bottle. In both lakes, triplicate samples were collected from a central location during the period of thermal stratification at 3 depths located in the epilimnion, metalimnion, and hypolimnion: 5, 10, and $35 \mathrm{~m}$ in Lake Pavin and 1, 5, and $12 \mathrm{~m}$ in Lake Aydat. Dissolved oxygen concentrations and temperature profiles were determined in situ using an Oxycal-SL probe.

The temporal and vertical variations in the concentrations of chlorophyll $a$, as well as those of viralrelated parameters (abundance, production, lytic activity, burst size) have been described in detail (cf. Bettarel et al. 2003, 2004).

HNF grazing on viruses was estimated using tracer particles and epifluorescence microscopy (Gonzàlez \& Suttle 1993). Primarily, a stock solution of tracer parti- cles was prepared from a concentrated suspension of $50 \mathrm{~nm}$ diameter Fluoresbrite plain microspheres (Polysciences) and protein-coated in $5 \mathrm{mg} \mathrm{ml}^{-1}$ albumin solution for $24 \mathrm{~h}$, to avoid clumping of the particles (Pace \& Bailiff 1987). Before in situ grazing experiments, the tracer solution was diluted with $0.02 \mu \mathrm{m}$ pore-size filtered lake water, and microspheres were added to $120 \mathrm{ml}$ of lake water in acidwashed glass bottles (triplicates) and incubated at in situ depth. Microbeads were added to the samples at a final concentration of $0.5 \times 10^{7} \mathrm{ml}^{-1}$ to account for approximately 10 to $20 \%$ of the virioplankton standing stock. Preliminary time-series experiments showed that $50 \mathrm{~nm}$ bead uptake by HNF was relatively linear during the first 15 to $20 \mathrm{~min}$. Thereafter, we suspect that particles were egested. Thus, incubations at each sampling depth (epi-, meta, and hypolimnion) were stopped after $20 \mathrm{~min}$ by adding ice-cold glutaraldehyde ( $2 \%$ final concentration). We acknowledge that egestion of a fraction of indigestible particles may happen sooner (i.e. 2 to 3 min) after ingestion (e.g. Boenigk \& Arndt 2002). To determine the uptake of beads by phagotrophic HNF, triplicate $10 \mathrm{ml}$ subsamples of each of the glutaraldehyde-fixed samples were filtered onto $0.8 \mu \mathrm{m}$ poresize Nuclepore filters, stained with primulin and examined via epifluorescence microscopy (Caron 1983). UV excitation was used to visualize 200 to $300 \mathrm{HNF}$ per sample $(\times 1.250)$, while blue-light excitation was used to enumerate beads present in the food vacuoles inside the flagellates. The ingestion rate (IR, virus $\mathrm{HNF}^{-1} \mathrm{~h}^{-1}$ ) of individual $\mathrm{HNF}$ was calculated by multiplying the mean number of beads ingested per protozoan per hour by the natural virusto-bead ratio. Clearance rate $\left(\mathrm{CR}, 1 \mathrm{HNF}^{-1} \mathrm{~h}^{-1}\right)$ was calculated by dividing IR by natural viral abundance. Grazing rate $\left(\mathrm{GR}\right.$, virus $\left.\mathrm{l}^{-1} \mathrm{~h}^{-1}\right)$ was calculated as follows: $\mathrm{GR}=\mathrm{IR} \times[\mathrm{HNF}]$. Finally, the removal rate of viruses from HNF grazing (expressed in percentage of viral production, VP), was determined by dividing VP (calculated in Bettarel et al. 2004) by GR. In order to examine affiliation between HNF grazing on viruses and bacteria, we herein refer to HNF bacterivory (estimated using $500 \mathrm{~nm}$ fluorescent latex microbeads) reported in Bettarel et al. (2004) for the same sampling event.

\section{RESULTS AND DISCUSSION}

\section{Methodological aspects}

The use of $50 \mathrm{~nm}$ diameter beads as virus analogues may underestimate predation on viruses. For example, discrimination of particles in the spectrum of virus size 
range has been clearly demonstrated by Gonzàlez \& Suttle (1993), who reported that HNF can show preferences for fluorescent labelled natural viruses (FLV) concurrently with $50 \mathrm{~nm}$ latex beads. However, each of our attempts to use the FLV method failed because of the weak optical signal from FLVs through HNF food vacuoles in our freshwater samples. Furthermore, the standard size of the latex beads used (50 nm diameter) represents the average viral capsid size in both lakes, since about $70 \%$ of viruses in Lake Aydat and Lake Pavin were smaller than $60 \mathrm{~nm}$ diameter (authors' unpubl. data). Overall, because the surface properties of virus capsids and latex beads differ, we are aware that the estimated IR, GR and CR may be underestimates, and thus should be extrapolated to nature with some care.

\section{HNF consumption of viruses}

The level of HNF grazing on viruses was, on average, not significantly different in Lake Pavin (mean = $3.2 \times 10^{6}$ viruses $\mathrm{l}^{-1} \mathrm{~h}^{-1}$ ) than in Lake Aydat (mean $=$ $2.9 \times 10^{6}$ viruses $\mathrm{l}^{-1} \mathrm{~h}^{-1}$ ) (Table 1 ). However, for both lakes, the lowest GR, along with the lowest flagellate abundances, were always recorded within the hypolimnion (Bettarel et al. 2003). In Lake Aydat, this layer was anoxic between July and October, while temperatures remained constantly low (mean $=4.00 \pm$ $0.05^{\circ} \mathrm{C}$ ) within the hypolimnion of Lake Pavin (see Fig. 1 in Bettarel et al. 2004). Both anoxic conditions and low temperatures have been shown to limit flagellate proliferation (Sherr et al. 1988, Weinbauer \& Höfle 1998). In contrast, viruses were grazed at higher rates in the metalimnion of the 2 lakes, where like their bacterial hosts, they are significantly more numerous (Bettarel et al. 2003). It is thus tempting to believe that virivorous organisms, like bacterivorous ones, should be able to optimize their food uptake by exploiting patches of high prey abundances.

Seasonally, peaks in GR occurred at the beginning and at the end of the period of thermal stratification in both lakes (Fig. 1), along with the maxima in bacterial, viral, and protistan abundances and activities (Bettarel et al. 2004). Interestingly, although HNF IR were similar in both lakes, individual CR were significantly higher in Lake Pavin (mean $=2.3 \times 10^{-2} \mathrm{nl} \mathrm{HNF}^{-1} \mathrm{~h}^{-1}$ ) than in Lake Aydat (mean $=0.7 \times 10^{-2} \mathrm{nl} \mathrm{HNF}^{-1} \mathrm{~h}^{-1}$ ). In the productive Lake Aydat, where bacteria and viruses are abundant, viruses may not represent an important component of HNF diet and may have been ingested passively along with the prokaryotic prey. Conversely, in Lake Pavin, the relatively low bacterial abundances may drive HNF to actively include viruses in their daily diet.
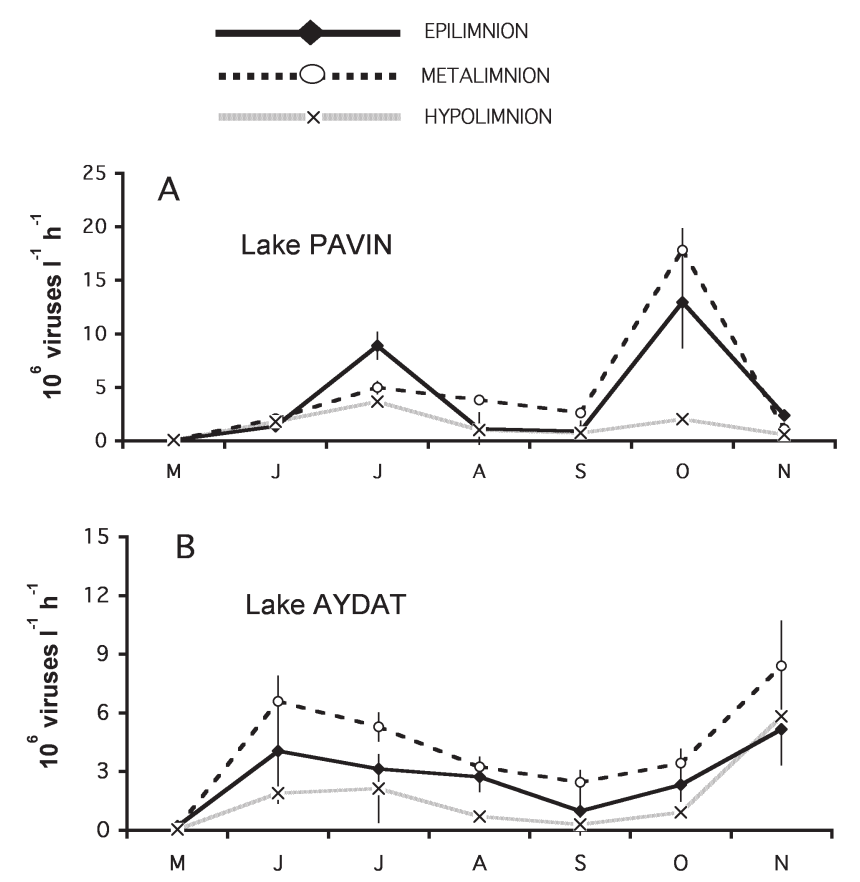

Fig. 1. Temporal and vertical variations of heterotrophic nanoflagellates (HNF) grazing rates on viruses in (A) Lake Pavinand and (B) Lake Aydat

\section{HNF grazing: virus vs bacteria}

The scenario described above does not seem unreasonable since seasonal CR estimated from ingestion of virus analogues (50 $\mathrm{nm}$ beads) were more highly correlated with those of bacterial analogues (500 nm beads) in Lake Pavin $\left(\mathrm{r}_{\text {epi }}=0.13, \mathrm{r}_{\text {meta }}=0.06, \mathrm{r}_{\text {hypo }}=0.14, \mathrm{n}=7\right)$ than in Lake Aydat $\left(\mathrm{r}_{\mathrm{epi}}=0.36, \mathrm{r}_{\text {meta }}=0.81, \mathrm{r}_{\text {hypo }}=0.95\right.$, $\mathrm{n}=7$ ). This might indicate that viruses and bacteria were grazed by the same nanoflagellate community in Lake Aydat, while in Lake Pavin this community may include more specific grazers on virus-sized particles, as already hypothesized by Gonzàlez \& Suttle (1993). However, our observations clearly contrast with those of Gonzàlez \& Suttle (1993), who reported a strong positive relationship between IR on virus-sized particles and their concentration, thus suggesting that the contribution of viruses to the nutrition of nanoflagellates is proportionally much greater at high viral densities. Although their conclusions are valuable for a given community, such may be not the case for all flagellate assemblages. The present study suggests that HNF grazers on virus-sized particles may occur preferentially in oligotrophic systems in which viruses may potentially represent a substantial food source. Further experiments are needed to confirm whether enough nutrition can be gained from viruses to maintain a population of virivory specialists under oligotrophic conditions. 
Table 1. Mean values (CV) for samples taken from Lake Pavin and Lake Aydat from May to November 2000, in the epilimnion $(\mathrm{E})$, the metalimnion $(\mathrm{M})$, and the hypolimnion $(\mathrm{H}) . \mathrm{FB}^{50} / \mathrm{FB}^{500}$ : ratio between clearance rates obtained from 50 and $500 \mathrm{~nm}$ fluorescent beads. HNF: heterotrophic nanoflagellates. Pavin/Aydat: ratio between mean values obtained in Pavin with those obtained in Aydat

\begin{tabular}{|c|c|c|c|c|c|}
\hline \multirow[t]{2}{*}{ Depth } & \multirow{2}{*}{$\begin{array}{c}\text { Grazing rates } \\
\left(10^{6} \text { viruses } \mathrm{l}^{-1} \mathrm{~h}^{-1}\right)\end{array}$} & \multirow{2}{*}{$\begin{array}{l}\text { Ingestion rates } \\
\left(\text { cell } \mathrm{HNF}^{-1} \mathrm{~h}^{-1} \text { ) }\right.\end{array}$} & \multicolumn{2}{|c|}{ Clearance rates } & \multirow{2}{*}{$\begin{array}{c}\text { Removal rates } \\
\text { (\% viral production) }\end{array}$} \\
\hline & & & $\left(\times 10^{-2} \mathrm{nl} \mathrm{HNF}{ }^{-1} \mathrm{~h}^{-1}\right)$ & $\mathrm{FB}^{50} / \mathrm{FB}^{500}(\%)$ & \\
\hline \multicolumn{6}{|l|}{ Lake Pavin } \\
\hline E & $4.0(115.8)$ & $0.5(92.2)$ & $2.1(129.2)$ & 11.9 & 4.8 \\
\hline M & $4.6(120.3)$ & $0.6(100.6)$ & $2.2(100.2)$ & 11.5 & 3.6 \\
\hline $\mathrm{H}$ & $1.0(67.2)$ & $0.2(45.0)$ & $2.7(157.6)$ & 10.3 & 3.8 \\
\hline Mean & $3.2(50.1)$ & $0.4(38.0)$ & $2.3(10.6)$ & $11.2(6.2)$ & $4.1(12.3)$ \\
\hline \multicolumn{6}{|l|}{ Lake Aydat } \\
\hline $\mathrm{E}$ & $2.7(59.3)$ & $0.3(75.7)$ & $0.6(65.4)$ & 3.1 & 1.0 \\
\hline M & $4.2(60.5)$ & $0.5(109.1)$ & $0.9(90.6)$ & 4.1 & 1.2 \\
\hline $\mathrm{H}$ & $1.7(108.6)$ & $0.2(133.4)$ & $0.5(118.3)$ & 2.5 & 0.3 \\
\hline Mean & $2.9(36.6)$ & $0.3(35.6)$ & $0.7(23.3)$ & $3.2(20.4)$ & $0.8(46.3)$ \\
\hline Pavin/Aydat & 1.1 & 1.4 & 3.3 & 3.5 & 5.1 \\
\hline \multicolumn{6}{|l|}{ ANOVA: } \\
\hline$F$ & 0.09 & 1.39 & 5.28 & & \\
\hline $\mathrm{df}$ & 41 & 41 & 41 & & \\
\hline $\mathrm{p}$ & 0.767 & 0.24 & 0.027 & & \\
\hline
\end{tabular}

Our calculated CR in Lake Aydat, determined using $50 \mathrm{~nm}$ diameter beads, represented only $3.2 \%$ of those with $500 \mathrm{~nm}$ beads, versus $11.2 \%$ in Lake Pavin (Table 1). For comparison, Gonzàlez \& Suttle (1993) reported that CRs of natural HNF assemblages feeding on viruses and virus-sized particles were only about $4 \%$ of those from HNF bacterivory.

\section{Impact of grazing on viral losses}

This study provides the first estimates of viral losses from HNF predation, with removal rates from HNF grazers averaging 4.1 and $0.8 \%$ of viral production in Lake Pavin and Lake Aydat, respectively. We suggest that viruses are probably of higher nutritional significance for HNF in oligotrophic systems than in productive ones. Nonetheless, despite the plausible underestimation of grazing activity on viruses from the latex bead method, phagotrophy by nanoflagellates is of minor importance as a loss process for natural virioplankton communities.

Higher contributions of flagellate grazing to bacterial mortality were also recorded in Lake Pavin (mean = $37.7 \%$ of bacteria production) than in Lake Aydat $($ mean $=18.5 \%)($ Bettarel et al. 2004). These results agree with the assumption that the control of bacterial production by protistan predation is higher in pelagic environments with low productivity (Strom 2000). However, more studies are unquestionably needed to confirm the higher contribution of HNF to viral mortality in low-productivity microbial loop dominated systems. With HNF responsible for less than $5 \%$ of viral mortality, the largest fraction of viral production in both lakes was surely controlled by factors other than flagellate predation. Besides lysogenic conversion, solar radiation (mostly UV-B wavelengths) has been identified as a prominent virucidal agent in aquatic systems (Noble \& Fuhrman 1997, Wilhelm et al. 1998, Fuhrman 1999), but temperature and heat-labile particulate material may also cause viral decay (Moebus 1992, Suttle \& Chen 1992).

\section{Nutritional significance of viruses: ecological implications}

According to Gonzàlez \& Suttle's (1993) calculations of the amount of carbon (C), nitrogen $(\mathrm{N})$ and phosphorus $(\mathrm{P})$ contained per single virus and bacterium, we estimated that ingested viruses would constitute only $0.56,0.71$ and $1.42 \%$ of $C, N$ and $P$, respectively, in the total diet of HNF in Lake Pavin, and only $0.13,0.20$, and $0.39 \%$ in Lake Aydat. Given mean virus:bacteria ratios of 7.1 and 9.0 reported in Lake Pavin and Lake Aydat, respectively (Bettarel et al. 2003), this clearly suggests that viruses are not as energetically valuable as bacteria in the HNF diet. Gonzàlez \& Suttle (1993) hypothesized that a virus:bacteria ratio $>50$ would render viruses a significant source of nutrients to nanoflagellates. However, one should keep in mind that, as with bacterioplankton, 'patches' of viruses likely occur with burst events.

Finally, our study supports Gonzàlez \& Suttle's (1993) conclusions that being grazed by protists is one possible fate for viruses in aquatic systems. In addition, 
our results suggest that although viruses would represent a diminutive food source for HNF (i.e. compared to bacteria), they still may not be inconsequential for the HNF diet, primarily in systems with low productivity. These results also extend the current concept of the viral loop, where the fraction of the virioplankton that is grazed by nanoflagellates does not participate in bacteria infection and is also paradoxically confiscated from the pool of DOM available for bacteria. This study strengthens the ecological key role of flagellates in aquatic systems and confirms the existence of a presumed new link between HNF and viruses in the functioning of aquatic microbial food webs. A question that now emerges is to what extent does ingestion of viruses by HNF represent a source of infection for these protists?

\section{LITERATURE CITED}

Bettarel Y, Sime-Ngando T, Amblard C, Carrias JF, Portelli C (2003) Virioplankton and microbial communities in aquatic systems: a seasonal study in two lakes of different trophy. Freshw Biol 48:810-820

Bettarel Y, Sime-Ngando T, Amblard C, Dolan J (2004) Viral activity in two contrasting lake ecosystems. Appl Environ Microbiol 70:2941-2951

Boenigk J, Arndt H (2002) Bacterivory by heterotrophic flagellates: community structure and feeding strategies. Antonie Leeuwenhoek 81:465-480

Bratbak G, Egge JK, Heldal M (1993) Viral mortality of the marine alga Emiliana huxleyi (Haptophycaea) and termination of algal blooms. Mar Ecol Prog Ser 93:39-48

Brussaard CPD (2004) Viral control of phytoplankton populations-a review. J Eukaryot Microbiol 51:125-138

Caron DA (1983) Technique for enumeration of heterotrophic and phagotrophic nanoplankton, using epifluorescence microscopy, and comparison with other procedures. Appl Environ Microbiol 46:491-498

Fischer UR, Velimirov B (2002) High control of bacterial production by viruses in a eutrophic oxbow lake. Aquat Microb Ecol 27:1-12

Fuhrman JA (1999) Marine viruses and their biogeochemical and ecological effects. Nature 399:541-548

Gonzàlez JM, Suttle CA (1993) Grazing by marine nanoflagellates on viruses and virus-sized particles: ingestion and digestion. Mar Ecol Prog Ser 94:1-10

Kapuscinski RB, Mitchell R (1980) Processes controlling virus inactivation in coastal waters. Wat Res 14:363-371

Mann NH (2003) Phages of the marine cyanobacterial picophytoplancton. FEMS Microbiol Rev 763:1-18

Middelboe M, Lyck PG (2002) Regeneration of dissolved

Editorial responsibility: John Dolan,

Villefranche-sur-Mer, France organic matter by viral lysis in marine microbial communities. Aquat Microb Ecol 27:187-194

Moebus K (1992) Laboratory investigations on the survival of marine bacteriophages in raw and treated seawater. Helgol Meeresunters 46:251-273

Noble RT, Fuhrman JA (1997) Virus decay and its causes in coastal waters. Appl Environ Microbiol 63:77-83

Noble RT, Fuhrman JA (2000) Rapid virus production and removal as measured with fluorescently labelled viruses as tracers. Appl Environ Microbiol 66:3790-3797

Pace ML, Bailiff MD (1987) Evaluation of fluorescent microsphere technique for measuring grazing rates of phagotrophic microorganisms. Mar Ecol Prog Ser 40:185-193

Sanders RW, Caron DA, Berninger UG (1992) Relationships between bacteria and heterotrophic nanoplankton in marine and freshwaters: an inter-ecosystem comparison. Mar Ecol Prog Ser 86:1-14

Sherr BF, Sherr EB, Rassoulzadegan F (1988) Rates of digestion of bacteria by marine phagotrophic protozoa:temperature dependence. Appl Environ Microbiol 54:1091-1095

Sherr EB, Sherr BF (1994) Bacterivory and herbivory: Key roles of phagotrophic protists in pelagic food webs. Microb Ecol 28:223-235

Šimek K, Pernthaler J, Weinbauer MG, Hornak K, Dolan JR, Nedoma J, Masin M, Amann R (2001) Changes in bacterial community composition and dynamics and viral mortality rates associated with enhanced flagellate grazing in a mesoeutrophic reservoir. Appl Environ Microbiol 67: $2723-2733$

Sime-Ngando T, Bettarel Y, Chartogne C, Sean K (2003) The imprint of wild viruses on freshwater microbial ecology. Recent Res Dev Microbiol 7:481-497

Strom SL (2000) Bacterivory: interactions between bacteria and their grazers. In Kirchman DL (ed) Microbial ecology of the oceans. Wiley-Liss, New York, p 351-386

Suttle CA (2000) Ecological, evolutionary, and geochemical consequences of viral infection of cyanobacteria and eukaryotic algae. In: Hurst CJ (ed) Viral Ecology Academic Press, San Diego, CA, p 247-296

Suttle CA, Chen F (1992) Mechanisms and rates of decay of marine viruses in seawater. Appl Environ Microbiol 58: 3721-3729

Weinbauer MG (2004) Ecology of prokaryotic viruses. FEMS Microbiol Rev 28:127-181

Weinbauer MG, Höfle MG (1998) Significance of viruses lysis and flagellate grazing as factors controlling bacterioplankton production in a eutrophic lake. Appl Environ Microbiol 64:431-438

Weinbauer MG, Rassoulzadegan F (2004) Are viruses driving microbial diversification and diversity? Environ Microbiol 6:1-11

Wilhelm SW, Weinbauer MG, Suttle CA, Jeffrey WH (1998) The role of sunlight in the removal and repair of viruses in the sea. Limnol Oceanogr 43:586-592

Wommack KE, Colwell RR (2000) Virioplankton: viruses in aquatic ecosystems. Microbiol Mol Biol Rev 64:69-114

Submitted: November 22, 2004; Accepted: March 3, 2005

Proofs received from author(s): April 20, 2005 